\title{
ELLEANTHUS LIGULARIS, A NAME FOR A RELATIVELY COMMON "NEW" SPECIES OF ELLEANTHUS SECT. CHLOIDELYNA
}

\author{
Robert L. Dressler ${ }^{1} \&$ Diego Bogarín \\ Jardín Botánico Lankester, Universidad de Costa Rica. P.O. Box 1031-7050 Cartago, Costa Rica, A.C.; \\ Centro de Investigación en Orquídeas de los Andes "Ángel Andreetta", Universidad Alfredo Pérez Guerrero, \\ Extensión Gualaceo, Ecuador. \\ ${ }^{1}$ Author for correspondence: rdressl@cariari.ucr.ac.cr
}

\begin{abstract}
Elleanthus ligularis is described and illustrated. The flowers of this species are apparently selfpollinating. Fruiting material has been collected in Colombia, Costa Rica, Cuba and Panamá, but the species remained nameless in the absence of flowers, and is here described as Elleanthus ligularis. Costa Rican plants in cultivation have flowered in late December, January, February and April. The species is similar to E. graminifolius, but the plants are more robust, with wider leaves and the blade of the lip is subquadrate, rather than obtriangular, with a very short base.
\end{abstract}

RESUMEN: Se ilustra y describe Elleanthus ligularis. Las flores de esta especie evidentemente se autopolinizan. Material con cápsulas se ha recolectado en Colombia, Costa Rica, Cuba y Panamá, pero se ha quedado anónimo, por falta de flores. Aquí se describe como Elleanthus ligularis. Plantas costarricenses en cultivo han florecido a fines de diciembre, en enero, febrero y abril. La especie se parece a E. graminifolius, pero las plantas son más robustas, con hojas más anchas y la lámina del labelo es subcuadrada, en vez de obtriangular, con la base muy corta.

Key Words: Elleanthus, Elleanthus ligularis, new species, Costa Rica, Epiendroideae, Sobraliinae, Orchidaceae.

Barringer (1985) added two additional Mesoamerican species to Elleanthus Section Chloidelyna, and the South American species have been treated by Løjtnant (1977), who transferred Adenoleu-therophora graminifolia Barb. Rodr. to Elleanthus and described E. isochiloides Løjtnant from Ecuador. At the same time, he mentioned two unnamed species allied to E. graminifolius (Barb. Rodr.) Løjtnant whose flowers had not been seen, both of which remained unnamed because no flowering material was available. He reported the species treated here as being known from Colombia, Costa Rica, Cuba and Panama. This species is one of the largest of Section Chloidelyna, and fruiting specimens have been in herbaria for years. It was called "species A" in Manual de las Plantas de Costa Rica (Dressler, 2003), where it was suggested that the species might flower in December or January. Two plants of this species flowered in late December and January in the Lankester Botanical Gardens, and others flowered in February or April. This is a rela- tively robust and wide-leaved member of Section Chloidelyna, and has been collected several times, but it is apparently self-pollinating, and, as far as we know, the plants that had been collected in the wild were all fruiting.

Elleanthus ligularis Dressler \& Bogarín, sp. nov.

Type: Costa Rica, Cartago: Jiménez, Pejivalle, La Marta, shores of Río Gato, 947'27.2”N $83^{\circ} 41^{\prime} 37.2^{\prime} \mathrm{W}, 750 \mathrm{~m}$, premontane wet forest, on trees along pastures edges and overhanging the river, 3 November 2006, collected by F. Pupulin 6360, R.L. Dressler, R. Gómez, A. Karremans \& G. Rojas. Cultivated in Lankester Botanical Garden, accession JBL-14915, flowered and pressed from cultivation, 14 Feb. 2006, R.L Dressler 6836B (holotype: CR, isotype: JBL-spirit).

Elleantho graminifolio (Barb. Rodr.) Løjtnant affinis, a qua habitu majore, foliis latioribus, base labelli latiore imprimis differt. 

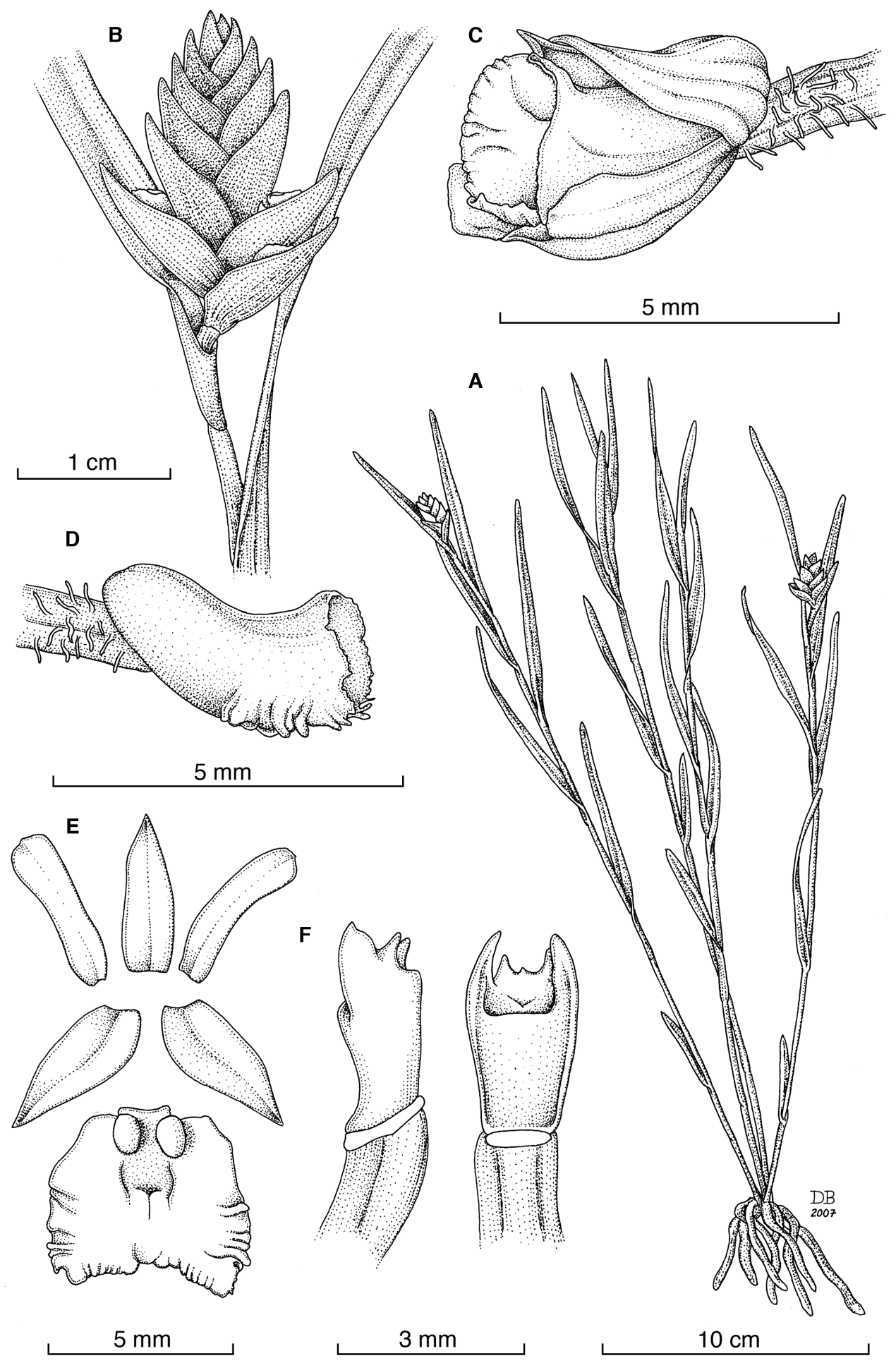

FiguRE 1. Elleanthus ligularis Dressler \& Bogarín. A - Habit. B - Inflorescence. C - Flower, in normal position. D - Lip, with sepals and petals removed. E - Perianth parts, flattened. F - Column, lateral and ventral views. Drawn from the holotype by Diego Bogarín. 
Plant epiphitic, cespitose. Roots $0.6-2 \mathrm{~mm}$ in diameter; stems $20-33 \mathrm{~cm}, \times 0.7 \mathrm{~mm}$ basally. Leaves up to 8 per stem, $4.8-9 \mathrm{~cm} \times 4-5.5 \mathrm{~mm}$, ligulate, apices tridenticulate, apically keeled beneath. Inflorescences subovate, 15-20 x 9-17 mm (without including the variable outermost bract, 13-25 mm long), other bracts $8-10.5 \times 5-6.5 \mathrm{~mm}$, carinate, narrowly obtuse when flattened. Ovary 3 $\mathrm{mm}$ dorsally, $2 \mathrm{~mm}$ ventrally. Dorsal sepal 4.2-4.5 x 1.3-1.5 mm, broadly lanceolate. Lateral sepals 4$4.5 \times 1.3-2 \mathrm{~mm}$, asymmetrically ovate-lanceolate. Petals 4.5-5 x 1.5-1.6 mm, spathulate-oblanceolate. Lip 4-5 × 5-6 mm, broadly obtriangular-subquadrate, the corners markedly fimbriate, 2 basal calli ca. $1 \times 0.7 \mathrm{~mm}$, short-stalked. Column $2.5 \mathrm{~mm}$ with anther $(c a .1 \mathrm{~mm})$.

Paratypes: Costa Rica. Alajuela: Upala, Bijagua, Zapote, desvío a la izquierda ca. $1 \mathrm{~km}$. después del puente sobre Río Zapote; 1045'21.0” N $85^{\circ} 04^{\prime} 56.9^{\prime} \mathrm{W}, 650-700 \mathrm{~m}$. Cultivated in Lankester Botanical Garden, accession JBL13885, pressed from cultivation, 6 Jan. 2007, $R$. Dressler $6836 B$ (USJ). Upala, Bijagua, Zapote, desvío a la izquierda ca. $1 \mathrm{~km}$ después del puente sobre Río Zapote en sentido Bijagua-Pueblo Nuevo, Finca La Escondida, $10^{\circ} 45^{\prime} 21.0 ” \mathrm{~N}$ 8504'56.9”'W, 650-700 m, bosque muy húmedo tropical, transición a premontano, epífitas en bordes de potreros, 3 Febrero 2006, D. Bogarín 2467, J. Barrantes, R.L. Dressler, R. Gómez \& A. Rojas
(CR). Limón: Pococí, Guápiles, $5 \mathrm{~km}$ al sur de la carretera, cerca de la Finca Tintoreras y el Río Blanco, $10^{\circ} 02^{\prime} 16.2^{\prime} \mathrm{N}, 83^{\circ} 53^{\prime} 02.1^{\prime} \mathrm{W}$, bosque muy húmedo tropical, R.L. Dressler 6761, D. Bogarín, J.Gómez-Laurito \& F. Pupulin (JBLspirit, CR). Pococí, Guápiles, San José-Limón highway, $\mathrm{km} \mathrm{47,} \mathrm{ca.} 500 \mathrm{~m}$ after the entrance of Rain Forest Aerial Tram, Quebrada Molinete,

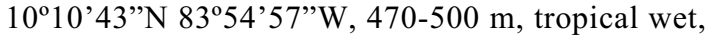
transition to premontane wet forest, epiphytic in primary forest along the river banks, 9 July 2004, F. Pupulin 5260 \& D. Bogarín (CR).

Other specimens of E. ligularis previously seen or reported: Costa Rica: Jiménez \& Lankester 2076 (AAU, AMES, Løjtnant, 1976); Limón: 700 - 900 m, 09²7’00”'N 08259'24”W, 24 Sep 1994, G. Gallardo \& E. Lépiz 302 (MO); Panama: Veraguas: Río Dos Bocas, 450 - $550 \mathrm{~m}, 08^{\circ} 33^{\prime} 03^{\prime \prime} \mathrm{N} 081^{\circ} 10^{\prime} 17^{\prime} \mathrm{W}, 31$ Aug 1974, T. Croat 27756 (MO).

Etymology: The epithet ligularis or "strap-shaped" refers to the characteristic form of the leaves long and narrow with the sides nearly parallel.

Elleanthus ligularis most closely resembles $E$. graminifolius, but the plants are much larger and the leaves are markedly wider; further, the lip is much wider near the base. We offer a key to the known Mesoamerican species of Section Chloidelyna, as well as E. muscicola, apparently the only other Mesoamerican species with conduplicate leaves.

\section{Key to the SPECIES OF ELLEANTHUS SeCtion CHLOIDELYNA}

Leaves conduplicate, linear to oblong-ovate; obtuse or tridentate; bracts always distichous

1. Leaves narrowly ovate or oblong, obtuse or retuse

Elleanthus Section Chloidelyna E. muscicola

1. Leaves linear to narrowly ligulate, acute to tridenticulate ......................................................................................... 2

2. Floral bracts well separated, not overlapping ……............................................................................................. 3

3. Leaves 1-2 cm long; inflorescence of 3-4 bracts on filiform rachis; plant sprawling, upper stems rooting and branching .................................................................................................................................... E. stolonifer

3. Leaves $3-5 \mathrm{~cm}$ long; inflorescence of $8-10$ bracts; stems rooting only basally .................................................... 4 4. Leaves 1-2 mm wide; inflorescence surpassing upper leaves; bracts 10-15 mm long ........... E. fractiflexus 4. Leaves less than $1 \mathrm{~mm}$ wide; upper leaves subequal to inflorescence; bracts 5-8 $\mathrm{mm}$ long .... E. poiformis

2. Floral bracts densely clustered, overlapping

5. Leaves mostly less than $1 \mathrm{~mm}$ wide; bracts sharply acuminate …….......................................... E. tillandsioides

5. Leaves mostly more than $1.5 \mathrm{~mm}$ wide; bracts obtuse or subobtuse ……………............................................... 6

6. Leaves $0.8-2 \mathrm{~mm}$ wide; lip obtriangular

E. graminifolius

6. Leaves $4-5.5 \mathrm{~mm}$ wide; lip subquadrate E. ligularis 
Acknowledgements. We thank Prof. Franco Pupulin for his continued support and collaboration. The scientific services of Costa Rican Ministry of Environment and Energy (MINAE) and its National System of Conservation Areas (SINAC) for issuing the collecting permits under which wild species treated in this paper were collected. The UK Darwin Initiative for the Survival of Species sponsored field work activities under the project "Conservation and Monitoring of Meso-American Orchids" (Ref.14001).

\section{Literature Cited}

Barringer, K. 1985. Three new species of Elleanthus (Orchidaceae) from Central America. Brittonia 37(3): 286-290.

Dressler, R. L. 2003. Elleanthus. Pp. 90-97 in: B.E. Hammel, M. H. Grayum, C. Herrera \& N. Zamora (eds.). Manual de las Plantas de Costa Rica Vol III. Orchidaceae-Zingiberaceae. Monogr. Syst. Bot. Missouri Bot. Gard. 93.

Garay, L. 1978. Studies in American Orchidaceae X. Bot. Mus. Leafl. Harvard Univ. 26(1): 1-38.

Løjtnant, B. 1976. Observations on the Elleanthus linifolius alliance (Orchidaceae) in S America. Botaniska Notiser 129: 445-454. 